\title{
Efek Hepatoprotektif Ekstrak Buah Merah (Pandanus conoideus Lam.) pada Hati Mencit Jantan Galur Swiss induksi dengan $\mathrm{CCl}_{4}$
}

\author{
Ari Satia Nugraha ${ }^{1 *}$, Ninisita Sri Hadi ${ }^{2)}$ dan Rr. Sri Untari Siwi ${ }^{2)}$ \\ 1) Program Studi Farmasi Universitas Jember \\ 2)Departemen Biomedik Program Studi Farmasi Universitas Jember \\ Jl. Kalimantan I/2, Jember, Jawa Timur 68121 \\ Diterima 20-05-2007 Disetujui 21-07-2008
}

\begin{abstract}
A research on red fruit (Pandanus conoideus Lam.) has been conducted to determine its hepatoprotective effect. This research was concern on three group of treatments, a blank treatment (water), a standard drug (curcumine containing) and red fruit extract treatment group. The liver destruction was induced by $\mathrm{CCl}_{4}$. The hepatoprotective effect was illustrated by SGOT - SGPT level of activity and percentage of cell destruction obtained from histopatogolic analysis. Compared to the blank group, which had level of SGOT-SGPT activity as $38224,40 \pm 2,92$ U/L and SGPT of $24128,00 \pm 5,22 \mathrm{U} / \mathrm{L}$, the red fruit treatment group showed a lower SGOT - SGPT activity (20112,4 $\pm 2,68 \mathrm{U} / \mathrm{L}$ and $18923,0 \pm 2,77 \mathrm{U} / \mathrm{L}$, respectively); while the standard drug treatment group showed level of SGOT and SGPT activity as $29732,4 \pm 1,85 \mathrm{U} / \mathrm{L}$ and $20640,8 \pm 3,78 \mathrm{U} / \mathrm{L}$, respectively. The histopatologic evaluation also illustrated similarity that the red fruit treatment group occupied the lowest percentage of hepatocyte destruction shown as percentage of cell degeneration and cell necrosis of $28,3 \%$ and $31,7 \%$, respectively. The standard drug treatment showed $78,3 \%$ of destruction based on degenerative cell destruction and $88,3 \%$ based on cell necrosis. Almost $100 \%$ of cell destruction was shown in the blank group. Based on these result, the red fruit extract possessed a liver cell protection activity against cell destruction caused by $\mathrm{CCl} 4$ exposure and even more active than a standard drug.
\end{abstract}

Keywords: Red fruit, Pandanus conoideus Lam., $\mathrm{CCl}_{4}$, SGOT - SGPT activity, hepatocyte destruction.

\section{PENDAHULUAN}

Prevalensi kerusakan hati di dunia menunjukkan jumlah yang serius untuk diwaspadai (Poli Z \& Parola 1997). Di tingkat daerah kecil pun, dalam hal ini Kabupaten Jember, Provinsi Jawa Timur, kejadian infeksi virus hepatitis menunjukkan jumlah yang cukup tinggi yang terjadi secara periodik (Dinkeskab Jember 2005). Kerusakan hati dapat disebabkan oleh infeksi maupun aktifitas senyawa kimia yang masuk ke dalam tubuh dengan berbagai macam mekanisme. Kerusakan hati yang diawali dengan meningkatnya steatosis dan fibrosis pada hati yang dalam kondisi kronis dapat menyebabkan kematian. Salah satu mekanisme patogenesis kerusakan hati adalah degradasi membran hepatosit yang dikarenakan oleh peroksidasi lemak (Kandalintseva et al, 2002). Reaksi peroksidasi dapat dipicu oleh paparan spesies oksigen reaktif (SOR) (Poli \& Parola 1997). Kondisi dan struktur membran sel berperan penting dalam melawan efek SOR. Asam lemak tidak jenuh pada membran sel dapat mengalami

*Telp \& Fax : +62 331324736

Email: arisatia@yahoo.com peroksidasi oleh SOR yang berakibat pada penurunan integritas dan fungsi membran sel dan akhirnya berimplikasi pada perubahan patologis yang serius (Halliwell 1987; Kandalintseva et al, 2002). Sistem fisiologis tubuh mempunyai kemampuan mengurangi kerusakan sel-sel oleh peroksidasi (Sies 1993). Namun demikian, apabila tubuh dalam kondisi lemah atau ketika paparan SOR terlalu banyak, maka mekanisme proteksi tambahan diperlukan. Salah satu bentuk proteksi tambahan ini adalah melalui konsumsi antioksidan yang banyak terkandung dalam bahan alam. Meskipun mekanisme proteksi sel sangatlah kompleks, tetapi asupan antioksidan disarankan dalam pencegahan dan pengobatan degenerasi sel hati yang disebabkan oleh reaksi oksidasi (Lieber 1997).

Penggunaan buah merah untuk pengobatan alternatif terhadap penyakit degeneratif dan kanker meningkat pada dekade ini, bahkan mampu mampu menggeser penggunaan buah mengkudu. Buah merah yang termasuk dalam ordo pandanalus merupakan tanaman endemik papua yang tumbuh alami di dataran tinggi ( $1500 \mathrm{~m} \mathrm{dpl}$ ) dengan variasi sekitar 35 jenis buah 
merah. Spesies yang paling banyak dipakai adalah Pandananus conoideus dengan buah merah marun, agak pendek dan biji agak besar dibandingkan dengan spesies yang lainnya (Budi \& Paimin 2005). Dalam penelitian-penelitian terdahulu, buah merah dilaporkan mempunyai kandungan senyawa antioksidan tinggi antara lain betakaroten dan tokoferol (Sathyabudi 2005). Kedua senyawa ini dapat digunakan untuk melawan species oksigen reaktif (SOR) dalam tubuh sehingga perubahan patologis dapat dicegah. Menurut Bass (1999) senyawa-senyawa yang mengandung gugus hidroksi atau polihidroksi, seperti karoten dan tokoferol, pada buah-buahan, sayur, dan beberapa tanaman lain berperan penting dalam aksi hepatoproteksi.

Meskipun data-data ilmiah tentang pemanfaatan buah merah dalam pengobatan masih relatif sedikit, tetapi sampai saat ini buah merah telah banyak digunakan oleh masyarakat untuk terapi pengobatan penyakit kanker, diabetes, rematik, dan tekanan darah tinggi (Budi \& Paimin 2005). Di dalam dunia kosmetika, buah merah digunakan sebagai bahan untuk memperlambat proses penuaan pada kulit.

Berdasarkan uraian di atas, buah merah mempunyai banyak kandungan senyawa aktif antara lain senyawa antioksidan yang diduga mampu menangkal kerusakan sel yang diakibatkan oleh reaksi oksidasi. Penelitian ini bertujuan untuk menguji potensi hepatoproteksi ekstrak buah merah sehingga dapat memberikan informasi, landasan ilmiah dalam pemanfaatan buah merah dan penelitian lebih lanjut.

\section{BAHAN DAN METODE}

Bahan dan Alat. Bahan yang digunakan meliputi ekstrak buah merah terstandarisasi, diperoleh dari PT. Saka Farma Laboratories - Semarang; Obat hepatoprotektor standar merk A (mengandung kurkumin), diperoleh dari produk industri farmasi nasional; Karbon tetraklorida $\left(\mathrm{CCl}_{4}\right)$; Formalin $10 \%$, zat warna Hematoksilin Eosin; xylol, alkohol 70\%, alkohol 80\%, alkohol 90\%, alkohol 96\%, alkohol absolut, SGPT-SGOT complete reagent test; CMC; metanol; aquadest semua dalam standar kimia.

Alat yang digunakan adalah timbangan hewan, sentrifuse; alat tes SGOT dan SGPT (Cobas Integra); tissue processor, mikroskop, mikrotom, oven, vial, spuit injeksi, sonde, alat bedah, tabung mikrosentrifugasi, water bath, hot plate, object glass, cover glass, dan alat-alat gelas yang sesuai

Hewan Uji. Hewan uji yang digunakan adalah mencit jantan galur Swiss (20-30 g), diperoleh dari Laboratorium Biomedik Farmasi Program Studi Farmasi Universitas Jember.

Percobaan Hewan Uji. Mencit galur Swiss sebanyak 30 ekor dibagi secara acak dalam 3 kelompok. Kelompok pertama sebagai kontrol negatif, kelompok kedua sebagai kontrol positif dan kelompok ketiga dan keempat sebagai kelompok perlakuan. Sebelum dilakukan perlakuan, semua kelompok hewan uji dipuasakan semalam. Kemudian selama 7 hari berturutturut kelompok pertama diberi aquadest $0.5 \mathrm{ml} / 20 \mathrm{~g} \mathrm{bb}$ mecit, kelompok kedua diberi obat hepatoprotektor standar yang mengandung kurkumin dengan dosis 5.2 $\mathrm{mg} / 20 \mathrm{~g}$ bb mencit dan kelompok ketiga diberi larutan buah merah dengan dosis 0,117 $\mathrm{ml}$ ekstrak/20 g bb mencit. Ekstrak buah merah dan obat standar diencerkan dalam larutan CMC 1\% sehingga semua perlakuan diberikan dengan volume pemberian $0,5 \mathrm{ml} /$ $20 \mathrm{~g} \mathrm{bb}$ mencit secara peroral. Setelah 7 hari pemberian, hewan uji dipuasakan makan selama 16 jam dan selama 3 hari berturut-turut semua kelompok hewan uji kecuali kontrol negatif diberi larutan $\mathrm{CCl}_{4} 0,1$ $\mathrm{ml} / 20 \mathrm{~g}$ bb mencit (p.o) (Thakore \& Mehendale 1991).

Pengambilan Darah Hewan uji. Pengambilan darah pada mencit dilakukan setelah hari ketiga pemberian $\mathrm{CCl}_{4}$. Darah mencit diambil melalui vena cavilla ocularis yang ada di mata dengan menggunakan kapiler. Darah kemudian ditampung dalam tabung mikrosentrifugasi untuk diambil serumnya yang kemudian dilakukan pengujian terhadap aktivitas SGOT dan SGPT.

Pengambilan Organ Hati Hewan Uji. Pengambilan organ hati dilakukan pada hewan uji yang berbeda namun diberi perlakuan yang sama dengan hewan uji yang digunakan untuk pengambilan darah untuk pengujian aktivitas SGOT dan SGPT. Hewan uji yang telah diberi perlakuan kemudian dibedah dan diambil organ hatinya. Organ hati yang didapat difiksasi dengan larutan formalin 10\% untuk dibuat preparat histopatologik. Kondisi organ dalam larutan formalin harus terendam seluruhnya dan waktu perendaman tidak kurang dari 24 jam.

Penentuan Aktivitas SGPT dan SGOT Serum Darah. Prinsip penetapan SGOT dan SGPT 
menggunakan metode kinetik yang sesuai dengan International Federation of Clinical Chemistry (IFCC) tanpa piroksidal-5-fosfat menggunakan alat COBAS INTEGRA. Penentuan aktivitas SGPT dan SGOT serum darah dilakukan pada hewan uji yang telah diberi $\mathrm{CCl}_{4}$ selama tiga hari. Serum yang diperoleh $(0,1 \mathrm{ml})$ dicampur dengan reagen SGPT atau SGOT $(1.0 \mathrm{ml})$ yang lebih dahulu dihangatkan pada suhu $37^{\circ} \mathrm{C}$. Campuran serum dan reagen dimasukkan ke dalam alat COBAS INTEGRA dan diukur absorbasinya pada $\lambda 340 \mathrm{~nm}$. Pengukuran dilakukan sebanyak empat kali dengan interval 30 detik (A0, A1, A2 dan A3). Hasil dari aktivitas SGOT dan SGPT dinyatakan dalam satuan unit/liter (U/L) yang merupakan banyaknya enzim dalam satu liter serum yang dapat menghasilkan NAD+ pada satuan waktu yang sama. Analisa data aktivitas SGPT dan SGOT kemudian dilakukan uji ANAVA satu arah. Apabila terjadi perbedaan secara signifikan maka akan dilanjutkan dengan LSD (Least Significant Difference).

Pemeriksaan Histopatologi Hati. Preparat histopatologi disiapkan dengan cara: fiksasi, dehidrasi dan clearing, embedding, bloking, pemotongan, pengecataan/pewarnaan dan mounting (Romzah 2005). Hewan uji dibunuh dengan dislokasi leher, organ hati diambil dan fiksasi dengan formalin 10 persen selama 24 jam kemudian dicuci dengan air. Dehidrasi dan clearing organ dilakukan dengan memasukkan organ hati ke dalam alkohol dengan konsentrasi 70\%, 80\%, 95\%, 96\%, alkohol absolut I, II, III, xylol I, II dan III masing-masing selama 30 menit. Kemudian dilakukan proses pelekatan organ dengan parafin (embedding) yaitu dengan memasukkan organ ke dalam parafin I yang masih cair, kemudian dimasukkan ke dalam oven suhu $55-56^{\circ} \mathrm{C}$ selama 30 menit dan diulangi lagi dengan parafin II dengan suhu oven $60^{\circ} \mathrm{C}$. Hasil embedding kemudian dibuat balok parafin (blocking) dengan menggunakan cetakan besi. Setelah parafin membeku dilakukan pemotongan blok parafin dengan menggunakan mikrotum dengan ketebalan 4 - $7 \mu \mathrm{m}$. Hasil potongan dimasukkan ke dalam water bath dengan suhu $42-45^{\circ} \mathrm{C}$ sampai jaringan mengembang kemudian dikeringkan dalam hot plate. Pewarnaan organ hati menggunakan Hematoxylin Eosin (HE) yang dilakukan setelah jaringan yang kering dimasukkan ke dalam xylol I, II dan III, masing masing selama 5, 4, dan 3 menit. Jaringan selanjutnya dimasukkan ke dalam alkohol absolut I (3 menit), alkohol absolut II (2 menit), dan alkohol absolut III (3 menit), alkohol 95\% (2 menit), alkohol 90\% (2 menit), alkohol 80\% (1 menit), alkohol $70 \%$ (1 menit), dan dicuci dengan air kran mengalir selama 5 menit. Proses selanjutnya jaringan dimasukkan ke dalam zat warna Hematoxylin Eosin (HE) selama 4-10 menit kemudian dicuci dengan air kran mengalir selama 10 menit, jaringan dimasukkan ke dalam eosin selama 3-8 menit kemudian dimasukkan berturut-turut ke dalam alkohol 70\% (1 menit), 80\% (2 menit), 90\% (3 menit) dan alkohol absolut I (3 menit), alkohol absolut II (3 menit) dan alkohol absolut III (3 menit). Selanjutnya jaringan dimasuk kedalam xylol I (3 menit), xylol II (4 menit) dan xylol III (5 menit). Proses terakhir adalah mounting yaitu penutupan gelas obyek dengan gelas penutup yang sebelumnya telah ditetesi menggunakan entellan atau kanada balsem.

Pengkajian Histopatologi dilakukan di bawah mikroskop cahaya dengan perbesaran 10 x 40 (Rusmiati \& Lestari 2004; Suarsana \& Budiasa 2005). Penentuan perubahan histopatologi meliputi degenerasi sel dan nekrosis dilakukan berdasarkan batasan yang dikemukakan oleh Romzah (2005). Hasil pemeriksaan preparat dianalisis secara deskriptif dan untuk membandingkan keseluruhan gambaran preparat dilakukan pengamatan hepatosit pada tiap lapang pandang. Pengamatan histopatologi hati diberi skor (Tabel 1) untuk setiap ulangan pada setiap kelompok perlakuan Perubahan gambaran histopatologi hati mencit normal bertanda negatif (-) diberi skor 0 dan bila bertanda positif (+) diberi skor 1-3 (Dewi 2002). Dari rata-rata skor perubahan gambaran histopatologi hati, kemudian dihitung persentasenya yang dinyatakan sebagai persentase kerusakan hati.

\section{HASIL DAN PEMBAHASAN}

Mencit yang digunakan dalam penelitian ini berjenis kelamin jantan karena sistem hormonal pada mencit jantan lebih stabil dibanding dengan mencit betina sehingga dapat meminimalkan variasi biologi karena pengaruh hormonal. Variasi teknis perlakuan dikurangi dengan pemakian menyamakan volume pemberian $(0,5 \mathrm{ml} / 20 \mathrm{~g}$ bb mencit).

Hasil pemeriksaan SGPT dan SGOT (Tabel 2 dan Gambar 1) menunjukkan perbedaan. Pada kontrol negatif yang diinduksi $\mathrm{CCl}_{4}$ tanpa pemberian hepatoprotektor menunjukan aktivitas SGPT dan SGOT 
paling tinggi dibandingkan dengan kelompok buah merah dan kelompok obat standar. Kelompok perlakuan dan kelompok pembanding menunjukkan perbedaan aktivitas SGPT dan SGOT yang menunjukkan bahwa buah merah mempunyai kemampuan hepatoprotektor lebih tinggi dibanding obat standar.

Hasil analisis varian satu arah diperoleh nilai $F$ hitung aktivitas SGPT (669.090) dan SGOT (42.660) yang lebih kecil dibandingkan $F$ tabel $(3,89)$ sehingga dapat disimpulkan bahwa aktivitas SGPT dan SGOT berbeda secara signifikan. Perbedaan ini dianalisis lagi dengan dengan LSD $(\alpha=0,05)$ dan diketahui selisih rata-rata dari masing-masing kelompok berbeda signifikan $(p<0,05)$ (Tabel 3 dan Tabel 4).

Aktivitas SGOT dan SGPT yang tinggi pada kontrol negatif menunjukkan reaktivitas karbon tetraklorida $\left(\mathrm{CCl}_{4}\right)$ dalam proses degenerasi sel hati yang ditandai dengan peningkatan aktivitas enzim SGPT dan SGOT.

Tabel 1. Skor perubahan gambaran histopatologi hati berdasarkan adanya degenerasi sel dan nekrosis

\begin{tabular}{lcll}
\hline $\begin{array}{l}\text { Bentuk } \\
\text { Perubahan }\end{array}$ & Nilai & Degenerasi Sel & Nekrosis Sel \\
\hline Negatif $(-)$ & 0 & $\begin{array}{l}\text { Tidak terjadi } \\
\text { degenerasi }\end{array}$ & Tidak terjadi \\
& nekrosis \\
Positif $(+)$ & 1 & $\begin{array}{l}\text { Degenerasi sempit } \\
\text { Nekrosis sempit }\end{array}$ & Nekrosis sedang \\
& 2 & $\begin{array}{l}\text { Degenerasi sedang } \\
\text { Degenerasi luas }\end{array}$ & Nekrosis luas \\
\hline
\end{tabular}

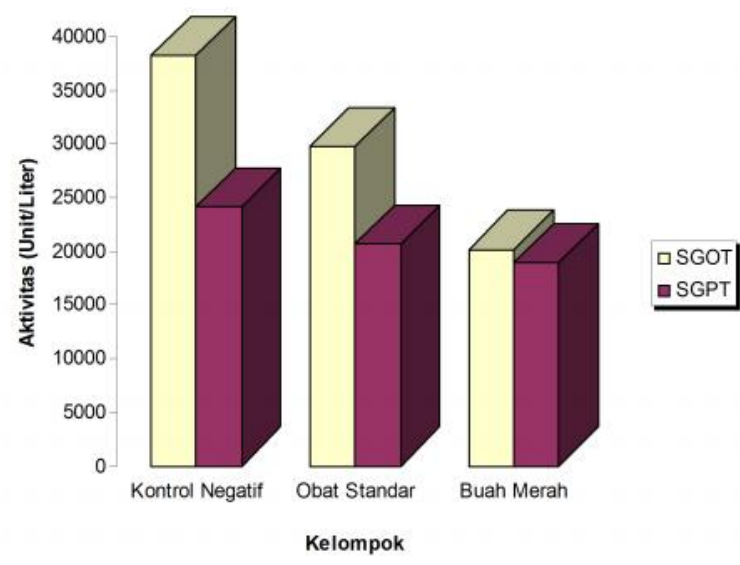

Gambar 1. Perbandingan rata-rata aktivitas SGOT dan SGPT

Tabel 2. Hasil pemeriksaan aktivitas SGOT dan SGPT

\begin{tabular}{lcc}
\hline \multicolumn{1}{c}{ Kelompok } & SGOT (Unit/l) & SGPT (Unit/l) \\
\hline Kontrol Negatif & $38224,4 \pm 2,92$ & $24128,0 \pm 5,22$ \\
Obat Standar & $29732,4 \pm 1,85$ & $20640,8 \pm 3,78$ \\
Buah Merah & $20112,4 \pm 2,68$ & $18923,0 \pm 2,77$ \\
\hline
\end{tabular}

Keterangan: Pengujian dilakukan pada suhu optimum $37^{\circ} \mathrm{C}$
Dalam penelitian ini, peningkatan terlihat jelas apabila dibandingkan dengan nilai aktivitas normal untuk mencit yaitu 76-208 U/L untuk SGPT dan 30-314 U/L untuk SGOT. Dalam model hepatitis oleh $\mathrm{CCl}_{4}$ (Saratikov 2001), molekul CCl4 mampu membentuk triklormetil peroksida radikal yang dapat merusak membran sel dan membran organela. Degenerasi organel-organel dalam sel memicu lisosom melepaskan enzim-enzim dalam darah sehingga aktivitas enzim SGPT dan SGOT meningkat. Menurut Lu (1995), meningkatnya aktivitas serum tersebut sebanding dengan jumlah sel yang mengalami kerusakan. Dalam penelitian ini, terjadi penurunan aktivitas SGOT dan SGPT pada kelompok pemberian buah merah dan obat standar (hepasil) dibandingkan dengan kontrol negatif. Data ini menunjukkan bahwa keduanya memiliki aktivitas sebagai hepatoprotektor yang didukung oleh aktivitas kandungan senyawa antioksidan. Buah merah mengandung antara lain, betakaroten dan tokoferol sedangkan obat standar mengandung senyawa kurkumin, silymarin, cynarin, dan echinacosid yang menunjukkan aktivitas sebagai antioksidan (Motterlini et al, 2002; Pellati et al, 2005; Toklu et al, 2008).

Tabel 3. Hasil uji LSD aktivitas SGPT

\begin{tabular}{llll}
\hline Perlakuan & \multicolumn{1}{c}{ Perlakuan } & $\begin{array}{c}\text { Selisih } \\
\text { Rata-Rata }\end{array}$ & Sig. \\
\hline Kontrol negatif & Buah Merah & $5205.00^{*}$ & .000 \\
& Obat Standar & $3487.20^{*}$ & .000 \\
Obat Standar & Kontrol Negatif & $3487.20^{*}$ & .000 \\
& Buah Merah & $1717.80^{*}$ & .011 \\
Buah merah & Kontrol negatif & $5205.00^{*}$ & .000 \\
& Obat Standar & $1717.80^{*}$ & .011 \\
\hline
\end{tabular}

Keterangan: *menunjukkan berbeda signifikan pada $\alpha=0.05$

Tabel 4. Hasil uji LSD aktivitas SGOT

\begin{tabular}{clcc}
\hline Perlakuan & \multicolumn{1}{c}{ Perlakuan } & $\begin{array}{c}\text { Selisih } \\
\text { Rata-Rata }\end{array}$ & Sig. \\
\hline Kontrol negatif & Buah Merah & $18112.00^{*}$ & .000 \\
& Obat Standar & $8492.00^{*}$ & .000 \\
Obat Standar & Kontrol Negatif & $8492.00^{*}$ & .000 \\
& Buah Merah & $9620.00^{*}$ & .000 \\
Buah merah & Kontrol negatif & $18112.00^{*}$ & .000 \\
& Obat Standar & $9620.00^{*}$ & .000 \\
\hline
\end{tabular}

Keterangan: *menunjukkan berbeda signifikan pada $\alpha=0.05$ 
Pemeriksaan histopatologi hati dilihat berdasarkan pengamatan lapang pandang secara acak. Pengamatan mikrokopis hanya mampu melihat melihat kerusakan hati berupa degenerasi dan nekrosis (Romzah 2005). Perbandingan hepatosit-hepatosit setelah perlakuan dapat dilihat di Gambar 2. Kerusakan heptosit ditunjukkan dari perubahan warna merah $(A)$ menjadi kebiruan (B). Degenarasi sel dan nekrosis ditandai dengan perubahan bentuk hepatosit dari simetris menjadi lebih besar dan tidak simetris. Hepatosit normal (C) nampak lengkap dengan inti dan bentuk yang simetris. Hepatosit dengan degenerasi sel (D) dan nekrosis (E) nampak adanya perubahan bentuk dan keberadaan inti sel.

Data rata-rata skor perubahan gambaran histopatologi berdasarkan degenarasi sel digambarkan pada Tabel 5 sedangkan data rata-rata skor perubahan gambaran histopatologi berdasarkan nekrosis digambarkan pada Tabel 6 . Hasil pemeriksaan preparat histopatologi menunjukkan adanya perbedaan pada masing-masing keadaan degenerasi sel dan nekrosis yang terjadi pada hepatosit yang tergantung pada perlakuan yang diberikan pada masing-masing kelompok. Persentase kerusakan hepatosit berdasarkan degenerasi sel dan nekrosis pada masingmasing kelompok ditunjukkan pada Tabel 7 dan Tabel 8.

Pemeriksaan histopatologi secara mikroskopis dapat menunjukkan degenerasi sel berupa degenerasi hidrofik dan nekrosis (kematian sel) hepatosit yang diakibatkan oleh pemberian $\mathrm{CCl}_{4}$. Menurut Prince dan Wilson (1984), secara umum degenerasi dikarenakan adanya penurunan kemampuan sistem pompa ion $\mathrm{Na}$ dalam sel yang menyebabkan pembengkakan sel atau degenerasi keruh. Pembengkakan sel secara mikroskopis terlihat sebagai sel dengan sitoplasma yang granular. Meningkatnya kadar air dalam sel mengakibatkan terjadinya degenerasi hidropik. Degenerasi sel yang terus menerus dan berlangsung cukup lama akan menyebabkan sel tidak dapat menjalankan fungsinya sehingga terjadi kematian sel atau nekrosis sel.

Hasil pemeriksaan aktivitas SGOT - SGPT dan pemeriksaan histopatologi menunjukkan bahwa
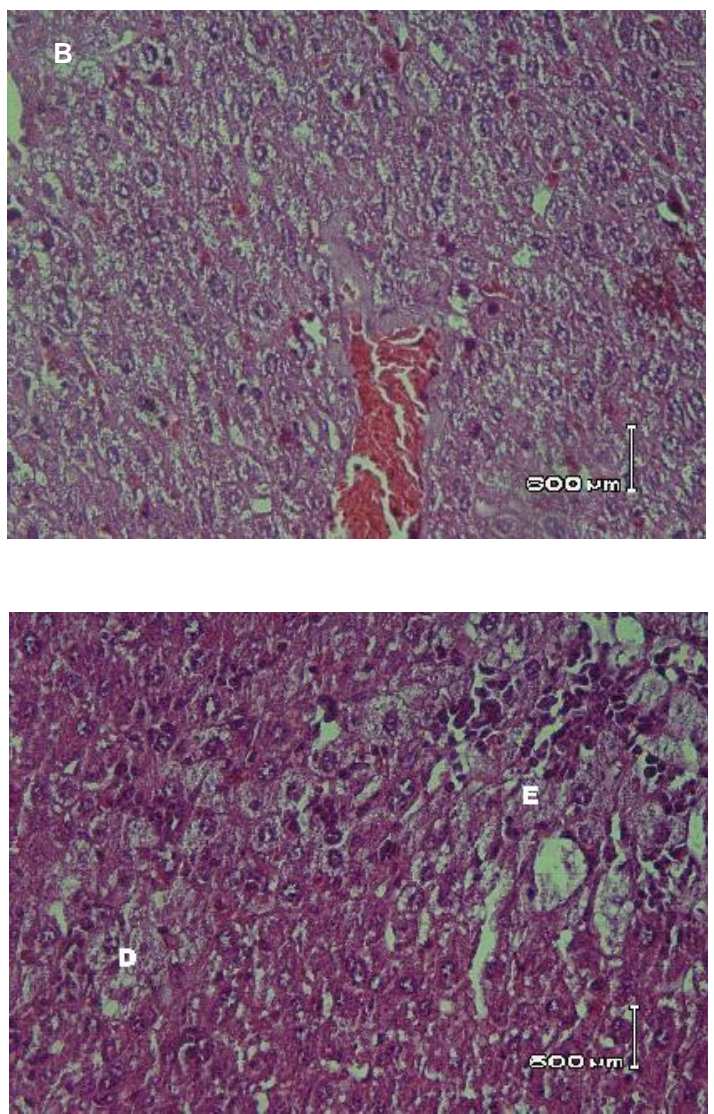

Gambar 2. Gambaran mikroskopis hepatosit mencit setelah perlakuan. (A) gambaran mikroskopis hepatosit normal; (B) gambaran mikroskopis kerusakan hati menyeluruh; (C) hepatosit normal; (D) hepatosit yang mengalami degenerasi sel; dan (E) hepatosit yang mengalami nekrosis 
dibandingkan dengan kedua kelompok yang lain (kontrol negatif dan obat standar), kelompok buah merah mengalami kerusakan hepatosit paling rendah yang ditunjukkan oleh rendahnya nilai aktivitas SGOT - SGPT dan rendahnya persentase kerusakan sel hati pada tingkat degenerasi sel dan nekrosis.

\section{KESIMPULAN}

Buah merah dapat menunjukkan aktivitas hepatoprotektif melawan kerusakan hati yang diinduksi oleh $\mathrm{CCl}_{4}$. Buah merah memiliki kemampuan hepatoprotektif yang lebih baik dibandingkan dengan

Tabel 5. Skor perubahan gambaran histopatologi hati berdasarkan degenerasi sel

\begin{tabular}{lccc}
\hline \multirow{2}{*}{ Kelompok } & \multicolumn{2}{c}{$\begin{array}{c}\text { Rata-Rata Skor } \\
\text { Preparat }\end{array}$} & Rata-Rata Total \\
\cline { 2 - 3 } & 1 & 2 & \\
\hline Kontrol Negatif & 2,7 & 2,6 & 2,65 \\
Obat Standar & 2,4 & 2,3 & 2.35 \\
Buah Merah & 1,1 & 0,6 & 0.85 \\
\hline
\end{tabular}

Keterangan: Rata-rata skor hepatosit normal adalah 0

Tabel 6. Skor perubahan gambaran histopatologi hati berdasarkan nekrosis

\begin{tabular}{lccc}
\hline \multirow{2}{*}{ Kelompok } & \multicolumn{2}{c}{$\begin{array}{c}\text { Rata-Rata Skor } \\
\text { Preparat }\end{array}$} & Rata-Rata Total \\
\cline { 2 - 3 } & 1 & 2 & \\
\hline Kontrol Negatif & 2,8 & 3,0 & 2,90 \\
Obat Standar & 2,6 & 2,7 & 2.65 \\
Buah Merah & 1,3 & 0,6 & 0.95 \\
\hline
\end{tabular}

Keterangan: Rata-rata skor hepatosit normal adalah 0

Tabel 7. Analisa data skor perubahan gambaran histopatologi hati berdasarkan degenerasi sel

\begin{tabular}{lcc}
\hline \multicolumn{1}{c}{ Kelompok } & $\begin{array}{c}\text { Rata-rata } \\
\text { keseluruhan }\end{array}$ & \% Kerusakan \\
\hline Kontrol Negatif & 2,65 & $88,3 \%$ \\
Obat Standar & 2.35 & $78,3 \%$ \\
Buah Merah & 0.85 & $28,3 \%$ \\
\hline
\end{tabular}

Tabel 8. Analisa data skor perubahan gambaran histopatologi hati berdasarkan nekrosis

\begin{tabular}{lcc}
\hline \multicolumn{1}{c}{ Kelompok } & $\begin{array}{c}\text { Rata-rata } \\
\text { keseluruhan }\end{array}$ & \% Kerusakan \\
\hline Kontrol Negatif & 2,90 & $96,7 \%$ \\
Obat Standar & 2.65 & $88,3 \%$ \\
Buah Merah & 0.95 & $31,7 \%$ \\
\hline
\end{tabular}

obat standar dalam mencegah terjadinya kerusakan sel hati yang ditunjukkan dengan tingkat aktivitas SGOT dan SGPT dan persentase kerusakan sel hati yang lebih rendah.

\section{UCAPAN TERIMA KASIH}

Ucapan terima kasih kami tujukan kepada Program Pendanaan Penelitian Internal Universitas Jember, sehingga penelitian dapat berjalan dengan lancar. Tim juga mengucapkan terima kasih kepada Ketua Bagian Kimia Farmasi dan Biomedik Farmasi, Program Studi Farmasi, Universitas Jember; Laboratorium Patologi Veteriner Kedokteran Hewan Universitas Airlangga dan Laboratorium Klinik Pramita Jember atas dukungan dan fasilitas pelaksanaan penelitian; Medicinal Chemistry Research Group, Program Studi Farmasi, Universitas Jember.

\section{DAFTAR PUSTAKA}

Bass, N.M. 1999. Is There any use for nontraditional or alternative therapies in patients with cronic liver desease? Curr. Gastroenterol Rep. 1: 50-56.

Budi, I. \& Paimin, P.R. 2005. Buah Merah. Jakarta: Penebar Swadaya.

Correlli, R.L. 1995. Acute and cronic hepatitis. Di dalam: Young, L. Y \& Koda-Kimble, M.A. (eds). Applied Therapeutics : The clinical use of drug. USA: Applied Therapeutics Inc.

Dewi, L.K. 2002. Uji toksisitas sub kronik jamu "X" secara mikroskopis pada hati mencit (Mus musculus) jantan. Skripsi. Surabaya: Fakultas Farmasi Universitas Surabaya.

Gee, J.P. \& Jim, L.K. 1995. Adverse effects of drugs on the liver. Di dalam: Young, L. Y \& Koda-Kimble, M.A. (eds). Applied Therapeutics : The clinical use of drug. USA: Applied Therapeutics Inc.

Dinkeskab. Jember. Data statistik Dinas Kesehatan Kabupaten Jember 2005.

Halliwell, B. 1987. Oxidant and human deseases. Some new concepts. FASEB J. 4: 441-445

Kandalintseva, N.V., Dyubchenko, O.I., Terakh, E.I., Prosenko, A..E., Shvarts, Y.S. \& Dushkin, M.I. 2002. Antioxidant and hepatoprotector activity of water soluble 4propylphenols containing hydrophilic groups in alkyl chains. Pharm. Chem. J. 36:177-180

Lieber, C.S. 1997. Role of oxidative stress and antioxidant therapy in alcoholic and nonalcoholic liver desease. Adv Pahrmacol 38: 601-628

Lu, F.C. 1995. Patologi. Jakarta: Fakultas Kedoteran Universitas Indonesia.

Motterlini, R., Foresti, R., Bassi, R. \& Green, C.J. 2000. Curcumin, an antioxidant and anti-inflammatory agent, induces heme oxygenase-1 and protects endothelial cells against oxidative stress. Free Radic. Biol. Med. 15: 130313112.

Pagana K.D. 2002. Mosby's manual of diagnosticand laboratory tests. St.Louis: Mosby Inc. 
Pellati, F., Benvenuti, S., Melegari, M. \& Lasseigne, T. 2005. Variability in the composition of anti-oxidant compounds in Echinacea species by HPLC. Phytochem. Anal 16: 77-85.

Poli, G \& Parola, M. 1997. Oxidative damage and fibrogenesis. Free Radic. Biol. Med. 22: 287-305

Prince, S. A. \& Wilson, L. M. 1984. Patofisiologi (Konsep Klinik Proses-Proses Penyakit). Edisi 2. Jakarta: Penerbit Kedokteran EGC.

Romzah, V. 2005. Pengaruh fasa air daun (Genarussa vulgaris, Nees) tehadap perubahan histopatologi hati, ginjal dan usus halus mencit jantan. Skripsi Fakultas Farmasi. Surabaya: Universitas Airlangga.

Rusmiati dan Lestari, A. 2004. Struktur histopatologis organ hepar dan ginjal mencit (Mus musculus L) jantan setelah perlakuan dengan ekstrak kayu Secang (Caesalpinia sappan L). BIOSCIENTIAE 1: 23-30.

Thakore, K.N \& Mehendale, H.M. 1991. Role of hepatocellular regeneration in $\mathrm{CCl} 4$ autoprotection. Toxicol. Pathol 19: 4758.

Saratikov, A. S., Litvinenko, Y. A., Burkova, V. N., Vengerovskii, A. I., Mozzhelina, T. K. \& Chuchalin, V. S.
2001. Antioxidant and hepatoprotector activity of lokein eplir combination. Pharm. Chem. J. 35: 340 - 342

Sathyabudi. 2005. Buah Merah. http:// www.buahmerahonline.com (10 Desember 2005).

Sies, H. 1993. Strategies of antioxidant defence, Eur. J. Biochem 215: 213-219.

Suarsana, I N. \& Budiasa, I K. 2005. Potensi hepatoprotektif ekstrak mengkudu pada keracunan parasetamol. Vet. J. Fakultas Kedokteran Hewan Universitas Udayana 6: 23-30.

Thakore, K.N \& Mehendale, H.M. 1991. Role of hepatocellular regeneration in $\mathrm{CCl}_{4}$ autoprotection. Toxicol. Pathol 19: 4758.

Teicher, P.A., Gee, J.P. \& Jim, L.K. 1995. Alcoholic cirrhosis. Di dalam: Young, L. Y \& Koda-Kimble, M.A. (eds). Applied therapeutics: The clinical use of drug. USA: Applied Therapeutics Inc.

Toklu, H.Z., Tunali-Akbay, T., Velioglu-Ogunc, A., Ercan, F., Gedik, N., Keyer-Uysal, M. \& Sener, G. 2008. Silymarin, the antioxidant component of Silybum marianum, prevents sepsis-induced acute lung and brain injury. J. Surg. Res. 145: 214-222 
